\title{
Response of Pomegranate to Different Organic Manures under Northern Dry Zone of Karnataka, India
}

\author{
B. Sangeeta Kurer*, D.R. Patil, Kantesh Gandolkar, Raghavendra K. Mesta, \\ M.S. Nagaraj, A.M. Nadaf and D.P. Prakash
}

Department of Fruit Science, College of Horticulture, Bagalkot-587 104, Karnataka, India

*Corresponding author

A B S T R A C T

An experiment was conducted to investigate the efficacy of organics on growth behaviour and fruit yield of pomegranate (Punica granatum L.) cv. 'Super Bhagwa' under northern

Keywords

Growth and yield, Organic manures, Pomegranate, RDN.

\section{Article Info}

Accepted:

04 September 2017

Available Online:

10 November 2017 dry zone of Karnataka during hasta bahar season of 2016-17. The experiment was laid out in a completely randomized block design with seven different sources of nutrients viz., $100 \%$ RDN (Recommended dose of nitrogen) through FYM, 100\% RDN through vermicompost, $100 \%$ RDN through poultry manure, $100 \%$ RDN through green manure with sun hemp, $100 \%$ RDN through sheep manure, $100 \%$ RDN through neem cake and recommended dose of fertilizer (400:200:200 N: $\mathrm{P}_{2} \mathrm{O}_{5}: \mathrm{K}_{2} \mathrm{O} \mathrm{g} /$ plant). Results revealed that $100 \%$ RDN through vermicompost recorded significantly highest vegetative growth (number of shoots/plant, shoot length, plant height and plant canopy spread in N-S and EW) and $100 \%$ RDN through poultry manure recorded significantly highest number of productive flowers, fruit set and yield. From the result it can be concluded that $100 \%$ RDN through vermicompost and $100 \%$ RDN through poultry manure performed best in improving the growth and yield respectively, of pomegranate cv. Super Bhagwa.

\section{Introduction}

Pomegranate is an important fruit crop of arid and semi-arid regions of the world. It is believed to be originated from Iran. It has both cultivated (Punica granatum L.) and wild types (Punica protopunica) and belongs to the family Lyrthaceae. In general, pomegranates are diploids with chromosome number, $2 n=2 x=16$. But, some of them are reported to have $2 n=2 x=18$ chromosomes (Eg. Double Flower, an ornamental variety which bears only flowers). India is one of the leading producers of pomegranate in the world having area over 1.93 lakh ha with annual production 21.98 lakh tones (Anon, 2017). In India, predominantly, pomegranate is cultivated in vast areas of marginal lands having very low organic carbon content (Marathe et al., 2015) and microbial population where yields were limited due to deficiency of more than 2-3 nutrients (Raghupati and Bhargava, 1998).

Switch over to the organic materials, which are natural source of nutrients, appears an effective alternative. Organic farming, using organic sources like FYM, animal excreta, oil cakes, green manures, crop residues etc., were the only source for supplying nutrients to crops in the past, is slowly regaining its past importance. Organic farming prohibits the use 
of synthetic agro-chemicals. It has more relevance to horticultural crops, which are largely consumed in fresh form immediately after harvest, unlike the field crops. Application of organic matter helps in better root growth and proliferation. Improvement in plant growth and nutrient supply (Singh et al., 2010; Sharma et al., 2011; Sudhakar et al., 2002). With the increasing health consciousness, the demand for organically produced pomegranate fruits is growing in Middle East, America and European countries. Keeping these points in mind, the present investigation was therefore, undertaken to study the effect of organic manures on growth and yield of pomegranate cv. Super Bhagwa.

\section{Materials and Methods}

The experiment was conducted in the Orchard of Fruit Science, Sector No.70, University of Horticultural Sciences, Udyanagiri, Navanagar, Bagalkot (Karnataka, India) during hasta bahar season of 2016-17. It is situated in the Northern Dry Zone (Zone-3) of Karnataka. The experiment was conducted on three year old pomegranate trees of cv. Super Bhagwa with seven treatments and three replications in completely randomized block design. The total numbers of trees included in the experiment were 84 and were spaced at $3.6 \mathrm{~m} \mathrm{X} 1.8 \mathrm{~m}$.

All the selected trees were almost uniform in growth and vigour. The trees were given uniform cultural operations during the course of investigation. All treatments were applied 15 days before bahar treatment except control (RDF) which was applied after bahar treatment. Full dose of FYM, vermicompost, poultry manure, green manure (sun hemp), sheep manure, neem cake and RDF were applied as basal dose. Observations on number of shoots, shoot length, plant height and plant canopy spread (N-S and E-W) were recorded during growth period. The numbers of productive flowers per plant were counted and the average numbers of flowers in each replication were calculated. The fruit set percentage was calculated by using the standard formula (Westwood 1988).

Number of fruits

Fruit set $(\%)=$

Number of productive flowers

Statistical analysis was done by using method of analysis of variance (ANOVA) for randomized complete block design (RCBD) by Fischer and Yates (1963). Whenever ' $F$ ' test was found significant for comparing the means of two treatments, critical difference (C. D. at 5\%) was worked.

\section{Results and Discussion}

$100 \%$ RDN through vermicompost recorded significantly higher number of shoots (45.73/plant), shoot length $(95.30 \mathrm{~cm})$, plant height $(3.97 \mathrm{~m})$ and plant canopy spread in both North-South $(2.82 \mathrm{~m})$ and East-West $(2.98 \mathrm{~m})$ directions (Table 1) and it was followed by $100 \%$ RDN through poultry manure. Better growth and development of plants with the application of 100 per cent RDN through vermicompost might be due to increased microbes in the rhizosphere which might have helped in enhanced release of growth factors like auxins, gibberellins and cytokinins in pomegranate (Mir et al., 2015).

These results are also in confirmation with Naik and Babu (2007) who reported that application of vermicompost resulted in highest number of shoots per plant in guava. Choudary (2016) also reported that vermicompost altered various enzymatic activities in plants such as peroxidase, catalase etc., which promotes cell elongation, root and shoot growth and carbohydrate metabolism in ber. 
Table.1 Nutrient status of different organic sources of nutrients

\begin{tabular}{|l|c|c|c|c|c|c|c|}
\hline \multicolumn{1}{|c|}{ Organic manure } & $\mathbf{p H}$ & $\begin{array}{c}\mathbf{E C} \\
\left(\mathbf{d S}-{ }^{\mathbf{1}}\right)\end{array}$ & $\begin{array}{c}\mathbf{O C} \\
(\mathbf{\%})\end{array}$ & $\begin{array}{c}\mathbf{N} \\
(\mathbf{\%})\end{array}$ & $\begin{array}{c}\mathbf{P}_{\mathbf{2}} \mathbf{O}_{\mathbf{5}} \\
(\mathbf{\%})\end{array}$ & $\begin{array}{c}\mathbf{K}_{\mathbf{2}} \mathbf{O} \\
(\mathbf{\%})\end{array}$ & $\mathbf{C}: \mathbf{N}$ \\
\hline FYM & 5.40 & 4.60 & 24.7 & 0.7 & 1.67 & 0.96 & $35: 01$ \\
\hline Vermicompost & 7.13 & 1.83 & 21.00 & 1.07 & 0.91 & 0.91 & $21: 01$ \\
\hline Poultry manure & 7.70 & 1.06 & 50.00 & 2.4 & 4.8 & 1.08 & $20: 01$ \\
\hline Sheep manure & 7.60 & 4.27 & 23.43 & 1.1 & 0.96 & 0.67 & $21: 01$ \\
\hline Neem cake & 5.40 & 4.62 & 31.43 & 1.03 & 0.64 & 0.87 & $30: 01$ \\
\hline Green manure (Sunhemp) & - & - & - & 3.21 & 0.48 & 0.83 & - \\
\hline
\end{tabular}

Table.2 Influence of different organic manures on vegetative growth of pomegranate cv. Super Bhagwa

\begin{tabular}{|c|c|c|c|c|c|}
\hline \multirow[b]{2}{*}{ Treatments } & \multirow[b]{2}{*}{$\begin{array}{l}\text { Number } \\
\text { of shoots }\end{array}$} & \multirow{2}{*}{$\begin{array}{l}\text { Shoot } \\
\text { length } \\
\text { (cm) }\end{array}$} & \multirow[b]{2}{*}{$\begin{array}{l}\text { Plant height } \\
\text { (m) }\end{array}$} & \multicolumn{2}{|c|}{ Plant spread (m) } \\
\hline & & & & $\begin{array}{l}\text { North- } \\
\text { South }\end{array}$ & $\begin{array}{l}\text { East- } \\
\text { West }\end{array}$ \\
\hline$T_{1}-100 \%$ RDN- FYM & 34.30 & 82.30 & 3.23 & 2.43 & 2.48 \\
\hline $\mathrm{T}_{2}-100 \%$ RDN-VC & 45.73 & 95.30 & 3.97 & 2.82 & 2.98 \\
\hline $\mathrm{T}_{3}-100 \%$ RDN-PM & 39.93 & 88.18 & 3.49 & 2.67 & 2.67 \\
\hline $\mathrm{T}_{\mathbf{4}-100 \%} \mathrm{RDN}-\mathrm{GM}$ & 37.60 & 85.33 & 3.50 & 2.57 & 2.66 \\
\hline $\mathrm{T}_{5-100 \%}$ RDN-SM & 36.57 & 84.97 & 3.25 & 2.31 & 2.60 \\
\hline $\mathrm{T}_{6-100 \%}$ RDN-NC & 36.27 & 79.84 & 3.00 & 2.28 & 2.58 \\
\hline $\begin{array}{l}T_{7 \text {. control }(\text { RDF- }} \\
\text { 400:200:200 g/plant) }\end{array}$ & 35.43 & 83.43 & 3.29 & 2.43 & 2.67 \\
\hline S Em \pm & 1.42 & 2.78 & 0.17 & 0.10 & 0.08 \\
\hline CD at $5 \%$ & 4.36 & 8.57 & 0.53 & 0.31 & 0.25 \\
\hline
\end{tabular}

FYM-Farm yard manure; VC-Vermicompost; PM- Poultry manure; GM- Green manure (sum hemp); SM-Sheep manure; NC- Neem cake; RDF- Recommended dose of fertilizers; RDN- Recommended dose of nitrogen

Table.3 Influence of different organic manures on number of productive flowers, fruit set and yield of pomegranate cv. Super Bhagwa

\begin{tabular}{|c|c|c|c|c|}
\hline Treatments & $\begin{array}{c}\text { Productive } \\
\text { flowers per plant }\end{array}$ & $\begin{array}{c}\text { Fruit set } \\
(\%)\end{array}$ & $\begin{array}{c}\text { Yield } \\
\text { (kg/plant) }\end{array}$ & $\begin{array}{l}\text { Yield } \\
\text { (t/ha) }\end{array}$ \\
\hline 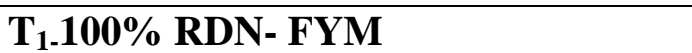 & 67.78 & 63.90 & 11.61 & 18.00 \\
\hline$T_{2} 100 \%$ RDN-VC & 63.00 & 52.55 & 9.00 & 13.89 \\
\hline $\mathrm{T}_{3.100 \%} \mathrm{RDN}-\mathrm{PM}$ & 85.15 & 67.16 & 13.43 & 20.73 \\
\hline $\mathrm{T}_{4.100 \%} \mathrm{RDN}-\mathrm{GM}$ & 69.18 & 58.83 & 10.24 & 15.80 \\
\hline $\mathrm{T}_{5.100 \%} \mathrm{RDN}-\mathrm{SM}$ & 66.21 & 66.91 & 10.79 & 16.65 \\
\hline $\mathrm{T}_{6}$-100\% RDN-NC & 76.11 & 66.19 & 12.72 & 19.65 \\
\hline $\mathbf{T}_{7-}$ control (RDF-400:200:200 g/plant) & 75.55 & 63.92 & 12.09 & 18.66 \\
\hline S Em \pm & 4.26 & 2.41 & 0.39 & 0.60 \\
\hline CD at $5 \%$ & 13.13 & 7.42 & 1.22 & 1.84 \\
\hline
\end{tabular}

FYM-Farm yard manure; VC-Vermicompost; PM- Poultry manure; GM- Green manure (sum hemp); SM-Sheep manure; NC- Neem cake; RDF- Recommended dose of fertilizers; RDN- Recommended dose of nitrogen 
Significantly higher number of productive flowers (85.15 plant $\left.^{-1}\right)$ and highest fruit set $(67.16 \%)$ were recorded by the plants supplied with $100 \%$ RDN through poultry manure (Table 3). The fruit set in pomegranate depends on number of hermaphrodite flowers (Anon., 2011). Phosphorous is a vital nutrient involved in stimulating and enhancing bud development, blooming and fruit set. Highest phosphorous content in poultry manure might help the plants to produce more flowers and fruits. In the present investigation, lowest numbers of flowers were recorded in 100\% RDN through vermicompost. Significantly higher yield of $13.43 \mathrm{~kg} /$ plant and $20.73 \mathrm{t} / \mathrm{ha}$ was recorded in plants supplied with $100 \%$ RDN through poultry manure and it was at par with $100 \%$ RDN through neem cake (Table 2). In poultry manure and neem cake treatments, increase in yield was $9.98 \%$ and $5.08 \%$, higher than control (RDF), respectively. More number of productive flowers and higher fruit set helped in increased yield under this treatment. These results corroborated with Marathe et al., (2017) who reported that, nutrients in organic manures were released slowly and made available throughout the growth period and resulted in better uptake of nutrients, plant vigour and yield of the plants in pomegranate. Lowest yield of $9.00 \mathrm{~kg} /$ plant and $13.89 \mathrm{t} / \mathrm{ha}$ was recorded with the application of $100 \%$ RDN through vermicompost. Lesser number of productive flowers and lesser fruit set percentage might have resulted in reduced number of fruits and yield in this treatment.

The results of the present investigation revealed that the nutritional requirement of pomegranate could be fulfilled with the exclusive use of organic sources without affecting growth performance and yield. It can be concluded that poultry manure could be harnessed for effective organic production of pomegranate. Thus, there is a need to address some key issues for enhancing pomegranate productivity in northern dry zone of Karnataka; recommendations include intensification of effort by extension workers to convince farmers of the advantage of using organic manures. Also organic manures should be made readily available to farmers at affordable prices.

\section{References}

Anonymous, 2011, Pomegranate growing manual, National Research Centre on Pomegranate.

Anonymous, 2017, All India second advance estimates of area and production of horticulture crops, $31^{\text {st }}$ May.

Choudhary R., 2016, Effect of organic manures and fertility levels on growth parameters of ber (Zizyphus mauritiana Lamk.) cv. Gola under semi-arid conditions. MSc, thesis submitted to Department of Horticulture S. K. N. college of agriculture, Jobner; S. K. N. Agriculture University Jobner- 303 329.

Fischer, R. R. and Yates, F., 1963, Stastical tables for biological, agricultural and medical research. Sixth edition, Oliver and Boyd, Tweedale Court, Edinberg, pp. 747-777.

Marathe, R. A. and Babu, D. K., 2015, Determination of sampling period and leaf position for critical nutrient analysis in pomegranate cv. Bhagwa. Indian J. Hortic., 72: 562-565.

Marathe, R. A., Sharma, J., Murkute, A. A. and Babu, D. K., 2017, Response of nutrient supplementation through organics on growth, yield and quality of pomegranate. Scientia Hort., 214: 114121.

Mir, M., Sharma, S. D. and Kumar, P., 2015, Nutrient dynamics: effect on cropping behavior, nutrient profile and quality attributes of pomegranate (Punica granatum 1.) under rainfed agroclimatic 
conditions. J. Plant Nutr, 38:83-95.

Naik, M. H. and Babu, R. S. H., 2007, Feasibility of organic farming in guava (Psidium guajava L.). Acta Hort., 735: 365-372.

Raghupathi, H. B. and Bhargavaa, B. S., 1998, Leaf and soil nutrient diagnostic norms for pomegranate (Punica granatum L.). Comm. in Soil Sci. and Plant Anal., 29: 19-20.

Sharma, S. D., Devi, M., Kumar, P., Bhardwaj, S. K. and Raj, H., 2011, Potential use of bio-organic and inorganic nutrient source dynamics for improving cropping behavior, soil biological properties, nutrient content and quality attributes of apricot (Prunus armeniaca L.). Comm. in Soil Sci. and
Plant Anal., 42: 1659-1674.

Singh, S. R., Zargar, M. Y., Singh, U. and Ishaq, M., 2010, Influence of bioinoculants and inorganic fertilizers on yield, nutrient balance, microbial dynamics and quality of strawberry (Fragaria $x$ ananassa) under rainfed conditions of Kashmir valley. Indian $J$. Agrl. Sci., 80: 275-281.

Sudhakar, G., Cristopher, A. L. and Rangaswamy, A., 2002, Effect of vermicompost application on the soil properties, nutrient availability, uptake and yield of rice-a review. Agri. Review, 23: $127-133$.

Westwood, M. N., 1993, Temperate Zone Pomology. Portland, OR: Timber Press.

\section{How to cite this article:}

Sangeeta Kurer, B., D.R. Patil, Kantesh Gandolkar, Raghavendra K. Mesta, M.S. Nagaraj, A.M. Nadaf and Prakash, D.P. 2017. Response of Pomegranate to Different Organic Manures under Northern Dry Zone of Karnataka, India. Int.J.Curr.Microbiol.App.Sci. 6(11): 86-90. doi: https://doi.org/10.20546/ijcmas.2017.611.011 